\title{
Evaluation of Visible Losses and Damage to the Ratoon Cane in the Mechanized Harvesting of Sugarcane for Different Displacement Speeds
}

\author{
Carmen Maria Coimbra Manhães*, Ricardo Ferreira Garcia, Delorme Correa Junior, \\ Francisco Maurício Alves Francelino, Helenilson de Oliveira Francelino, \\ Carlos Mair França Gonçalves dos Santos \\ Laboratory of Agricultural Engineering, State University of North Fluminense Darcy Ribeiro, Campos dos \\ Goytacazes, Brazil \\ Email: ${ }^{*}$ carmenmanhaes@yahoo.com.br
}

Received 30 June 2014; revised 15 August 2014; accepted 3 September 2014

Copyright $@ 2014$ by authors and Scientific Research Publishing Inc.

This work is licensed under the Creative Commons Attribution International License (CC BY). http://creativecommons.org/licenses/by/4.0/

(c) (i) Open Access

\begin{abstract}
This study aimed at quantitatively evaluating the sugarcane losses and the damage caused to the ratoon cane while using the Case IH A8800 harvester in different displacement speeds; it was conducted in the municipality of Campos dos Goytacazes, in Rio de Janeiro, Brazil. Three speeds were used as treatment $\left(2 \mathrm{~km} \cdot \mathrm{h}^{-1}, 3 \mathrm{~km} \cdot \mathrm{h}^{-1}\right.$, and $\left.4.5 \mathrm{~km} \cdot \mathrm{h}^{-1}\right)$, and each treatment was composed of six rows of harvested ratoon, each with a length of $290 \mathrm{~m}$. In order to evaluate the quantitative losses in $t^{\cdot h a^{-1}}$ and the percentage of losses, the remaining sugarcane, left on the field after harvesting, was collected. The sampling frame was set to every $50 \mathrm{~m}$, dividing the borders by $40 \mathrm{~m}$; the measurement for each sampling area was of $20 \mathrm{~m}^{2}$, with five repetitions. In order to evaluate the damage caused to the ratoon canes, we chose a visual methodology to classify the damage degrees, ranging from one to four. There was no significant difference in losses when comparing different speeds. Therefore, it is more advantageous and economically viable to use the speed of 4.5 $\mathbf{k m} \cdot \mathrm{h}^{-1}$, which collects more in less time.
\end{abstract}

\section{Keywords}

Harvesting, Mechanization, Displacement Speed, Sugarcane

\footnotetext{
${ }^{*}$ Corresponding author.

How to cite this paper: Manhães, C.M.C., Garcia, R.F., Junior, D.C., Francelino, F.M.A., Francelino, H.O. and dos Santos, C.M.F.G. (2014) Evaluation of Visible Losses and Damage to the Ratoon Cane in the Mechanized Harvesting of Sugarcane for Different Displacement Speeds. American Journal of Plant Sciences, 5, 2956-2964.

http://dx.doi.org/10.4236/ajps.2014.520312
} 


\section{Introduction}

The culture of sugarcane (Saccharum spp.) is amongst the most important cultures in Brazilian agribusiness [1], with a significant participation not only in the economy of the country, but also worldwide. Its sub products are used in the production of fuel and in the generation of electric energy, as well as acting as a raw material for the chemical industry and as supplements for animal foods [2].

In the production of cane, one of the main operations is the harvesting. Until recently, the sugar and ethanol sector depended exclusively on human workforce to carry out the harvesting of sugarcane [1]. The harvest must meet the supply of sugar and ethanol plants, maintaining the quality at a low cost. However, the operational and economical performance of the harvest is influenced by a number of systematically interrelated variables [2].

For the crop of 2013-2014, the area under sugarcane cultivation is still expanding. However, in the state of Rio de Janeiro, the opposite is true: the cultivated area has been suffering continuous reductions since the crop of 2010-2011. In 2010-2011, the area comprised 51,330,000 hectares, whereas, in 2013-2014, the number was reduced to $35,870,000$ hectares, corresponding to a reduction of $30.1 \%$ at the end of three crops [3].

Coagro ("Agri-Industrial Cooperative of the State of Rio de Janeiro Ltd.”), located in the municipality of Campos dos Goytacazes, Rio de Janeiro, Brazil, harvested 25\% of its total sugarcane production with the use of machinery for the 2011-2012 crop, which is a result of the investment in equipment acquisition and of the hiring of new machinery, as well as of the hiring of professionals from different states with experience in the process of harvesting. Thus, the municipality of Campos dos Goytacazes is meeting the requirements of the Rio de Janeiro State Act 5990 of 20 June 2011, which aims at gradually eliminating the burning of cane straw [4].

In the northern region of the state, which is the most expressive in the production of sugarcane-especially regarding the municipality of Campos dos Goytacazes, its culture is still the main agricultural activity; however, its productivity is below $50 \mathrm{t} \cdot \mathrm{ha}^{-1}$ [5]. In this region, the process of mechanized harvesting is still responsible for many losses of raw material, which are caused by factors that still need clarification [4]. [6] classified the quantitative losses in the mechanized harvesting of sugarcane following the categories: stump, billets, fixed piece, loose piece, splinters, top, whole cane, and shrapnel; the sum of these categories is accounted for by total losses.

Studies have observed that, in the manual harvesting, losses hardly surpass 5\%. However, when machinery is involved, these losses can reach $15 \%$ or more, in some cases, which directly reflect productivity numbers [7].

[8] described several factors related to visible losses in the mechanized harvesting, amongst which are: the speed of the harvester, the variety, the preparation of the area, the training of the staff, and the maintenance of the equipment involved.

The displacement speed of sugarcane harvesters is directly influenced by culture and terrain conditions; therefore, faster-operating machinery will account for higher operational capacity. This may lead to an increase in losses, for the mass to be processed is greater; therefore, the speed is to be adjusted considering the plot and the size and productivity of the plantation [9].

In these ways, it is necessary to evaluate the losses in sugarcane harvesting for operational failures to be corrected.

The study at hand aimed at evaluating the visible losses of raw materials and the damage caused to the ratoon cane in the mechanized harvesting by using three different displacement speeds for the Case A8800 harvester.

\section{Materials and Methods}

The research was conducted in the municipality of Campos dos Goytacazes/RJ, in an area reserved for the mechanized harvesting of sugarcane. This area belongs to a supplier to Coagro. Geographical coordinates: $21^{\circ} 37^{\prime} 16^{\prime \prime} \mathrm{S}$ and $41^{\circ} 15^{\prime} 48^{\prime \prime} \mathrm{W}$.

The climate of the Campos dos Goytacazes municipality if classified as Aw according to the Köppen classification, i.e., hot and humid with a rainy summer, with an average temperature of $23.2^{\circ} \mathrm{C}$. June is the coolest month of the year (average temperature of $20.1^{\circ} \mathrm{C}$ ), whereas February is the warmest (average temperature of $26^{\circ} \mathrm{C}$ ). The soil is classified as red-yellow latosol, medium texture [10].

The piece of machinery utilized for this research was the Case IH A8800 harvester.

The experiment was divided in three different speeds: $2.0,3.0$, and $4.5 \mathrm{~km} \cdot \mathrm{h}^{-1}$. We chose a completely randomized design, with five repetitions.

The collection of data on visible losses was conducted in a delimited area after harvesting, where the leftover sugarcane left on the field was collected for each treatment. 
The experimental area for each treatment was composed of six rows of harvested ratoon, each with a length of $290 \mathrm{~m}$. In these six rows, which refer to each speed of displacement, the leftover sugarcane was collected while setting the sampling frame for the two central rows to every $50 \mathrm{~m}$, dividing the borders by $40 \mathrm{~m}$. The sampling area for the experiment was set to $2 \mathrm{~m}$ width vs. $10 \mathrm{~m}$ length, for a total of $20 \mathrm{~m}^{2}$, with five repetitions, such as Figure 1 demonstrates. The losses in $\left(t \cdot h^{-1}\right)$ and the percentage of losses per treatment were calculated from the data on the masses of each type of loss out of the five repetitions.

The visible sugarcane and straw losses were collected, separated and weighted according to the classification proposed by [6], as demonstrated in Table 1 .

The visible losses were converted in tons per hectare, following Equation (1):

$$
\mathrm{P}=\frac{\mathrm{m}}{\mathrm{a}} 10
$$

$\mathrm{P}$ : visible losses, $\mathrm{t} \cdot \mathrm{ha}^{-1}$;

$\mathrm{m}$ : collected mass in the area, $\mathrm{kg}$;

a: sample area, $\mathrm{m}^{2}$.

For the total losses, the value was calculated in percentage, following the Equation (2):

$$
\mathrm{P} \%=\frac{\mathrm{P}}{\mathrm{P}+\operatorname{prod}} 100
$$

$\mathrm{P} \%$ = total losses, $\%$;

prod = cane field productivity, $\mathrm{t} \cdot \mathrm{ha}^{-1}$.

In order to evaluate the damage caused to the ratoon cane, we chose a visual methodology by [11], which was adapted from [12]. It serves to quantify the damage in degrees seen in Figure 2. Fifty randomly chosen ratoon canes were chosen for each treatment.

The results for the masses of each type of loss and the data on the damage sustained to the ratoons were submitted to the analysis of variance, and the averages of the treatments were compared by using Tukey's test at a probability of $5 \%$, aiming to compare the visible losses between the different speeds. All the data were statistically analyzed by the software SAEG.

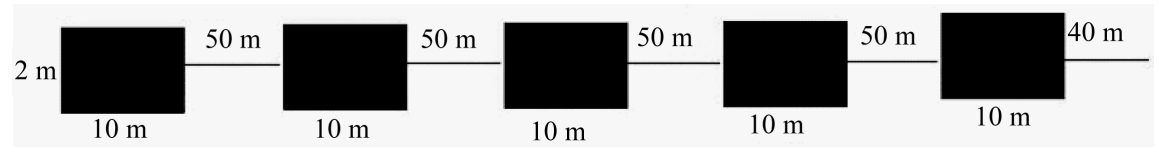

\begin{tabular}{|c|c|c|c|}
\hline CLASSIFICAÇÃO DOS DANOS & $G R A U$ & LIMITE INFERIOR & LIMITE SUPERIOR \\
\hline SEMDANOS & 1 & & \\
\hline DANOS PERIFÉRICOS & 2 & & \\
\hline RACHADURA & 3 & & D \\
\hline FRAGMENTADO & 4 & & \\
\hline
\end{tabular}

Figure 1. Model of sampling for the comparison of visible sugarcane losses.

Figure 2. Methodology used to classify the damages to the rations according to [11] and adapted by [12]. 
Table 1. Description of the types of loss.

\begin{tabular}{ll}
\hline Billets & Fraction of the thatch with the characteristic cut of the machete in both extremities. \\
Whole cane & Fraction of cane with size equal to or greater than $2 / 3$ of the total length, attached to the soil by its roots or not. \\
Top & Fraction of the thatch left in the soil and attached to the pointer. \\
Fixed piece & Medium cane segment (greater than $0.2 \mathrm{~m}$ ) that is necessarily attached to the soil. \\
Loose piece & Medium cane segment (greater than $0.2 \mathrm{~m}$ ) that is necessarily not attached to the soil. \\
Splinter & Segmented fraction of the billet. \\
Shrapnel & Fraction of the thatch cut above the soil, attached to the roots, with length smaller than or equal to 0.2 m. \\
Stump & Sum of every loss.
\end{tabular}

Source: [6].

\section{Results and Discussion}

The characteristics of the studied plantation are on Table 2.

The estimated productivity for the culture was much greater than the average for the region, whose average productivity was below $50 \mathrm{t}^{\mathrm{h}} \mathrm{ha}^{-1}[5]$. This result may be related to the fact that it was the first sugarcane harvesting after renovating the plantation and to the systematization of the terrain being specifically designed for mechanized harvesting, with an adequate distance of $1.5 \mathrm{~m}$ between rows.

\subsection{Visible Losses of Raw Material}

Several scientific studies have already been conducted in order to evaluate the raw material losses with the harvester on the field, highlighting the researches by [1] [13]-[17], which evaluated the losses in function of the speed of displacement.

To minimize the visible losses in the mechanized harvesting process, it is necessary that the area that will receive the harvester not have great differences in the level of the terrain and that it be standardized regarding the distance between planted rows and the length of the areas and that it have overturning control.

The differences amongst the types of losses were not significant when comparing different speeds (Table 3).

The data found in this research agree with those found by authors such as [15], which evaluated the effect of four displacement speeds of the harvester on sugarcane losses on the field in the state of Mato Grosso do Sul and observed that the loss indices were not influenced by the increase in the speed of displacement of the harvester.

Likewise, [14] evaluated the performance of a harvester with steer tires in a plantation previously systematized with the mechanical harvesting in mind in four displacement speeds: $1.5,3.0,5.0$, and $7.0 \mathrm{~km} \cdot \mathrm{h}^{-1}$. The results showed that there was no influence of the displacement speed on the total raw material losses.

[1] and [13] also did not find any significant different in the losses by varying the displacement speed of the harvester.

On the other hand [16], while analyzing the influence of the increase in the displacement speed of the harvester on the visible losses of raw materials, concluded that there is a significant increase in the visible loss when a higher displacement speed is associated to the greater pressure of the base cut and of the exhaustor, especially when analyzing total losses. The data collected by these authors agree with those found by [17], who evaluated two displacement speeds ( 3.2 and $3.6 \mathrm{~km} \cdot \mathrm{h}^{-1}$ ) and found greater loss values with higher speed.

[9] affirmed that the harvesters might work with higher speeds, offering greater quantities of raw materials, with higher quality and lower visible losses on the field.

These results show that the influence of the displacement speed of the harvester on the amount of visible losses does not follow a general rule, for it depends on the conditions of the experimental area, of the chosen harvester, of the operator, of the synchronism between the machine and the overturning of the applied speeds. We cannot infer that the behavior of a harvester will be the same while working under different conditions.

The differences amongst the types of losses for Treatment 1 were not significant; the loose pieces were numerically found in greater quantities (Table 3). This type of loss accounts for 30\% of the total losses (Figure 3). The average total loss was of $8.54 \mathrm{t} / \mathrm{ha}$, which corresponds to $9.6 \%$ of the total losses in the evaluated speed. 
Table 2. Characteristics of the plantation.

\begin{tabular}{|cc}
\hline Characteristics of the culture & \\
\hline Estimated productivity of the farming $\left(\mathrm{t} \cdot \mathrm{ha}^{-1}\right)$ & 89.1 \\
Average length of the thatches $(\mathrm{m})$ & 2.37 \\
Average diameter of the thatches $(\mathrm{mm})$ & 28.6 \\
\hline
\end{tabular}

Table 3. Comparison of the averages of the types of loss between different speeds and their percentages of loss.

\begin{tabular}{cccc}
\hline Types of loss & Speed $1: 2 \mathrm{~km} \cdot \mathrm{h}^{-1}$ & Speed $2: 3 \mathrm{~km} \cdot \mathrm{h}^{-1}$ & Speed 3: $4.5 \mathrm{~km} \cdot \mathrm{h}^{-1}$ \\
\hline Billets & $0.49 \mathrm{Aab}$ & $0.42 \mathrm{Aa}$ & $0.29 \mathrm{Aa}$ \\
Top cane & $0.00 \mathrm{Ab}$ & $1.05 \mathrm{Aa}$ & $0.43 \mathrm{Aa}$ \\
Fixed piece & $0.20 \mathrm{Ab}$ & $2.01 \mathrm{Aa}$ & $0.73 \mathrm{Aa}$ \\
Loose piece & $1.61 \mathrm{Aa}$ & $2.56 \mathrm{Aa}$ & $1.17 \mathrm{Aa}$ \\
Splinter & $0.56 \mathrm{Aab}$ & $1.34 \mathrm{Aa}$ & $0.52 \mathrm{Aa}$ \\
Shrapnel & $0.20 \mathrm{Ab}$ & $0.57 \mathrm{Aa}$ & $0.23 \mathrm{Aa}$ \\
Stump & $0.00 \mathrm{Ab}$ & $0.16 \mathrm{Aa}$ & $0.31 \mathrm{Aa}$ \\
Whole cane & $0.46 \mathrm{Aab}$ & $0.43 \mathrm{Aa}$ & $0.99 \mathrm{Aa}$ \\
Total losses & $3.52 \mathrm{~A}$ & $8.54 \mathrm{~A}$ & $4.67 \mathrm{~A}$ \\
$\%$ of total losses & $4.0 \%$ & $9.6 \%$ & $5.2 \%$ \\
\hline
\end{tabular}

Values followed by the same letter (capital case) dot not differ significantly amongst themselves within the same row. Values followed by the same letter (lower case) dot not differ significantly amongst themselves within the same column according to Tukey's test.

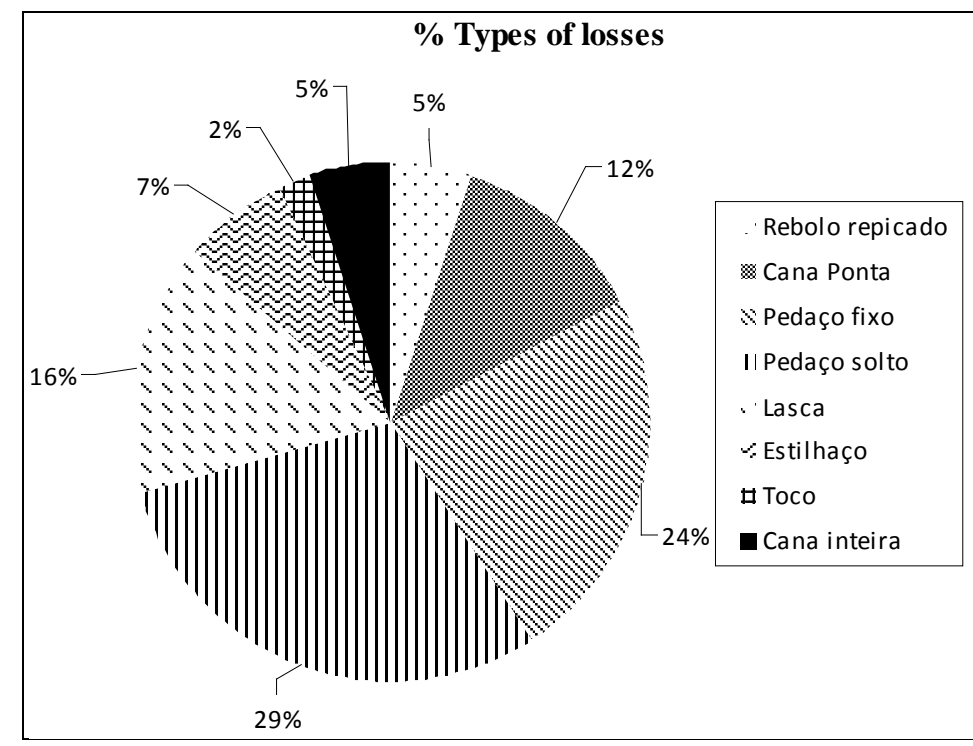

Figure 3. Percentage of the types of losses for Treatment 1.

The differences amongst the types of losses for Treatment 2 were not significant; the loose pieces were numerically found in greater quantities (Table 3). This kind of loss accounts for $25 \%$ of the total losses (Figure 4). The average total loss was of $4.67 \mathrm{t} / \mathrm{ha}$, which corresponds to $5.2 \%$ of the total losses in the evaluated speed.

The differences amongst the types of losses for Treatment 3 were significant; the loose pieces were numerically found in greater quantities (Table 3). This kind of loss accounts for $45 \%$ of the total losses (Figure 5). The average total loss was of $3.52 \mathrm{t} / \mathrm{ha}$, which corresponds to $4.0 \%$ of the total losses in the evaluated speed.

According to [18], the result found for the type of loss with greater quantities of loose pieces is justified by the fact that they directly indicate the influence of the rotation of the primary extractor. The rotation of the primary extractor utilized in this research was of $750 \mathrm{rpm}$. This number is higher than the value recommended by 


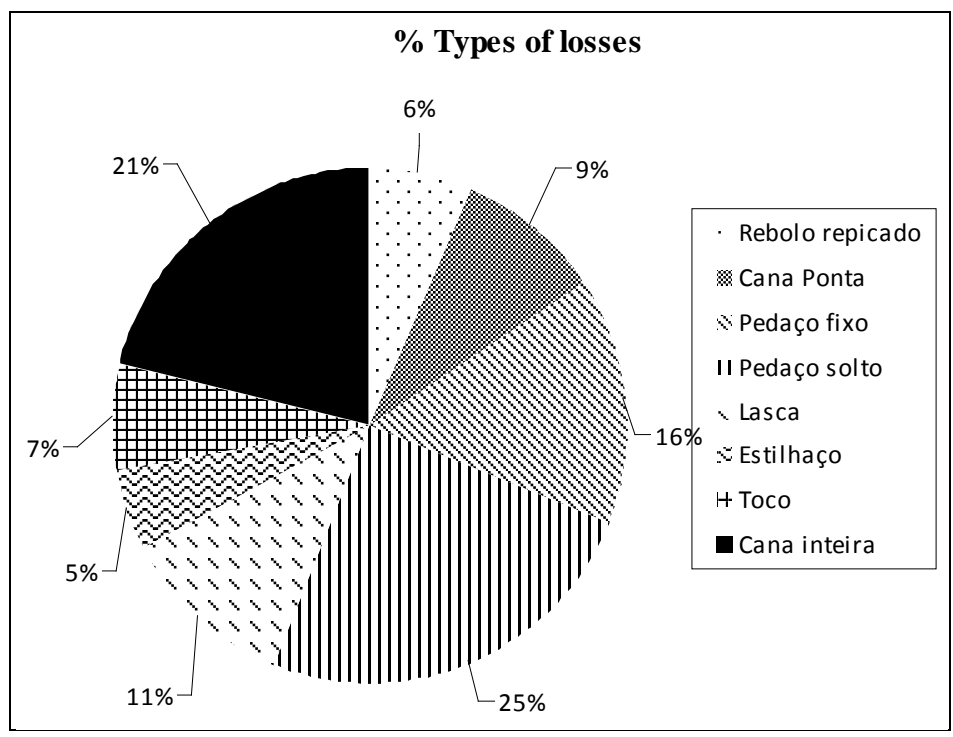

Figure 4. Percentage of the types of losses for Treatment 2.

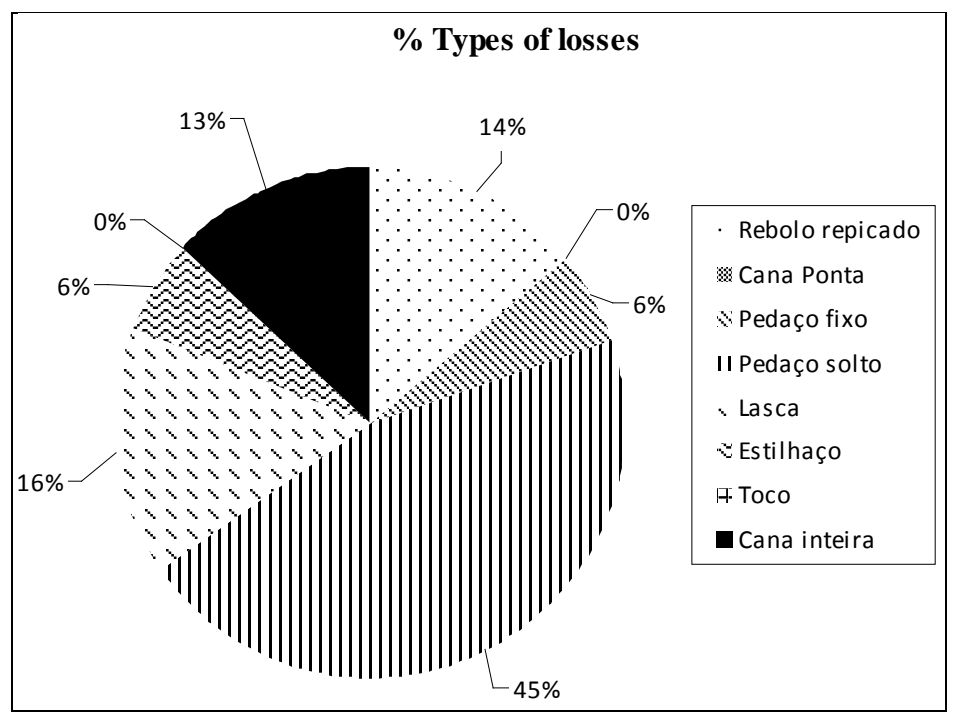

Figure 5. Percentage of the types of losses for Treatment 3.

manufacturers, which would range from 110 and $600 \mathrm{rpm}$. The higher value was utilized due to the great quantities of green leaves and straw on the plantation at the time of harvesting, since no desiccant was used prior to the experiment. Therefore, if the rotation of the exhauster were within the recommended limit, the level of impurities in the sugarcane would be beyond acceptable. However, augmenting the rotation of the primary exhauster can diminish the amount of impurities, but, on the other hand, this process also augments the amount of losses of splinters and loose pieces. According to [19], as the rotation of the primary exhauster is augmented, the billets are sucked along with the straw and the dirt and then launched onto the field; when going through the exhausters, the billets are hit by the paddles, which contributes to the increase of splinters and loose pieces, therefore also increasing losses.

[18] also found higher quantities of loose pieces, much like the findings of this research. [19] and [20] also found greater quantities of loose pieces while evaluating the Case A7700 harvester, which was the model manufactured prior to the one studied in this research. The two models share several sectors.

According to [8], losses greater than $4.5 \%$ are classified as "high". The loss percentages on this paper are considered high for Treatments $1 \& 2$ and medium for Treatment 3. Different authors have also found high total 
losses; [16] [19]-[21] found, while studying the subject, the following numbers: 4.7\%, 4.96\%, 9.3\%, and 12.5\%.

\subsection{Degree of Damage to the Ratoon}

The damage sustained to the ratoon may lead to a higher incidence of fungi and ratoon diseases, for its fragmentation causes a wound that becomes an entryway for insects and fungi. The damages also influence the capacity of the ratoon to resprout; the greater the damage is, the higher is the probable incidence of plagues and diseases and the lower is capacity of resprouting.

Table 4 demonstrates that the statistic differences between the damage degrees were only significant for Degree 1 , which was more commonly found at the highest speed $\left(4.5 \mathrm{~km} \cdot \mathrm{h}^{-1}\right)$. The other degrees did not demonstrate a significant difference between speeds. This results shows that the highest displacement speed led to greater values of the desired degree, which is Degree 1 (no damage), meaning that the high speed is indicated to avoid greater damages to the ratoons when under the conditions that the present study met.

For Treatment 1, Degree 2 was found in greater number, for a total of $38 \%$ of the evaluated ratoons, followed by Degrees 4, 3 \& 1 (Table 4). It means that the damage found the most often was peripheral; the most uncommon was not to find any damage, which occurred in only $6 \%$ of the ratoons (Figure 6).

In Treatment 2, Degree 2 was the most found, accounting for 34\% of the ratoons, followed by Degrees 4, 3 \& 1 (Table 4, Figure 7). It means that the damage found the most often was peripheral; the most uncommon was not to find any damage, which occurred in $16 \%$ of the ratoons.

In Treatment 3, Degree 2 was the most found, accounting for 32\% of the ratoons, followed by Degrees 3, 4 \& 1 (Table 4, Figure 8). It means that the damage found the most often was peripheral; the most uncommon was not to find any damage, which occurred in only $12 \%$ of the ratoons.

Table 4. Comparison of the damage degrees to the ratoons between different speeds.

\begin{tabular}{cccc}
\hline Damage degree & Speed 1: $2 \mathrm{~km} \cdot \mathrm{h}^{-1}$ & Speed 2: $3 \mathrm{~km} \cdot \mathrm{h}^{-1}$ & Speed 3: $4.5 \mathrm{~km} \cdot \mathrm{h}^{-1}$ \\
\hline 1-No damage & $6 \mathrm{AB}$ & $3 \mathrm{~B}$ & $8 \mathrm{~A}$ \\
2-Peripheral damage & $16 \mathrm{~A}$ & $19 \mathrm{~A}$ & $17 \mathrm{~A}$ \\
3-Cracking & $15 \mathrm{~A}$ & $17 \mathrm{~A}$ & $15 \mathrm{~A}$ \\
4-Fragmentation & $13 \mathrm{~A}$ & $11 \mathrm{~A}$ & $10 \mathrm{~A}$ \\
\hline
\end{tabular}

Values followed by the same letter do not differ significantly amongst themselves within the same row (Tukey, 5\%).

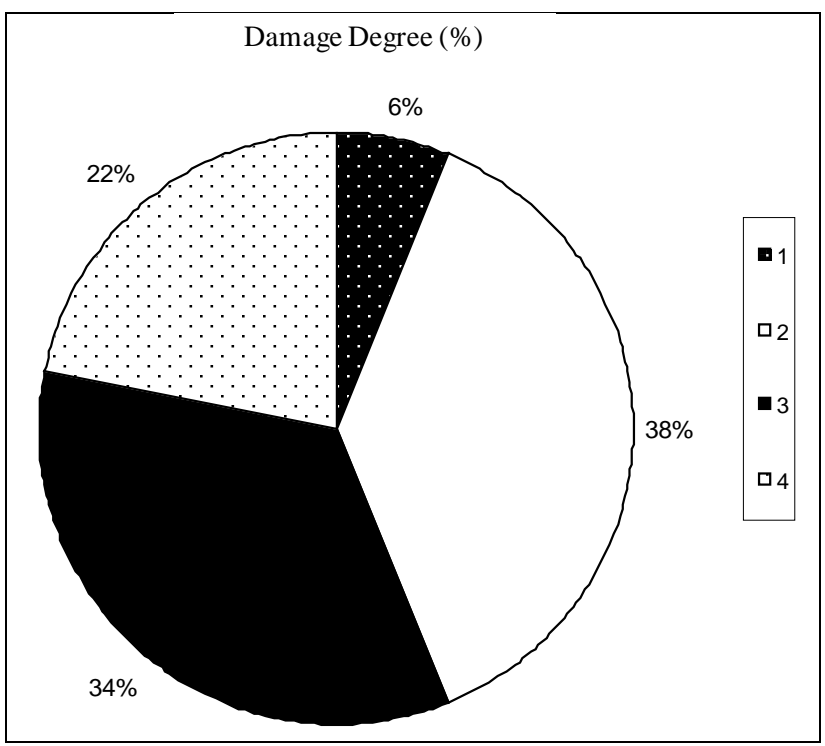

Figure 6. Percentage of damage degree for Treatment 1. 


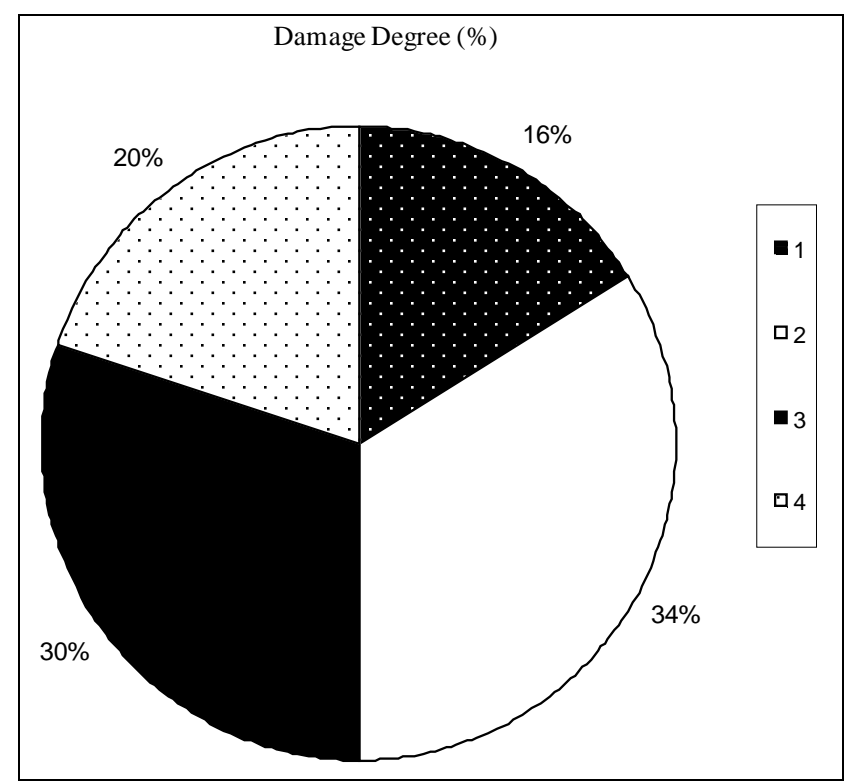

Figure 7. Percentage of damage degree for Treatment 2.

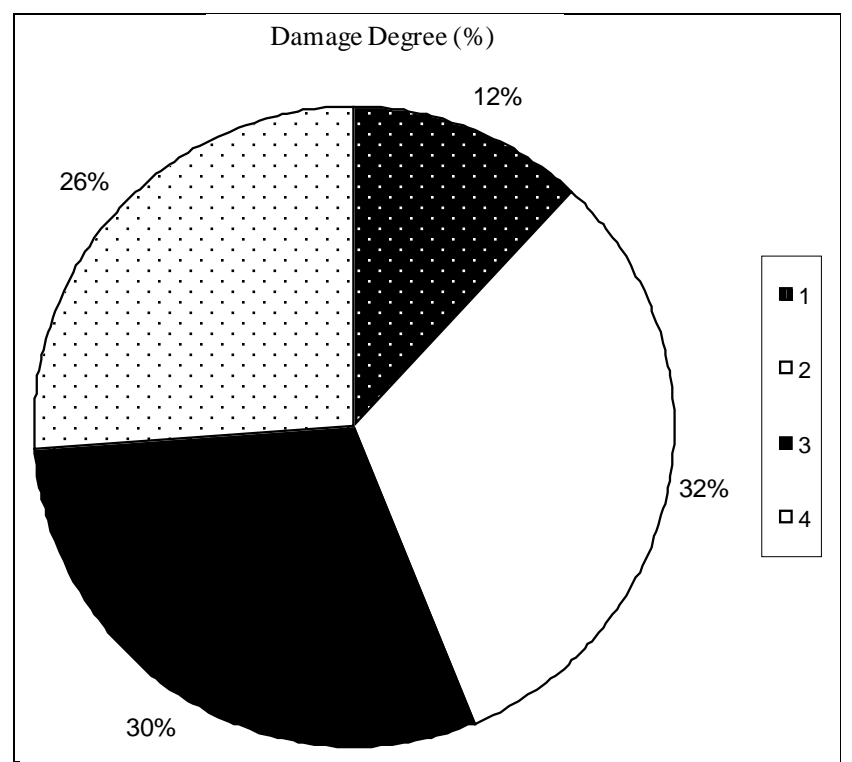

Figure 8. Percentage of damage degree for Treatment 3.

\section{Conclusions}

Under the conditions met in this study, the displacement speed of the harvester did not significantly affect the visible losses of the crop, but it did influence the damage to the ratoon.

Damage Degree 1 (no damage) was influenced by the different speeds, for it was found the most often when the highest speed, corresponding to $4.5 \mathrm{~km} \cdot \mathrm{h}^{-1}$, was applied.

Thus, it is clear that, regardless of the displacement speed applied to the Case A8800 harvester, there is no significant loss. It is more advantageous to apply the speed of $4.5 \mathrm{~km} \cdot \mathrm{h}^{-1}$ to the harvester, which collects more in less time when compared to the other velocities studied.

\section{Acknowledgements}

To CNPq, for the concession of a doctorate scholarship to the first author. 


\section{References}

[1] Rosa, E.J., José, J.V., Salvestro, A.C. and Gava, R. (2009) Perdas visíveis de cana-de-açúcar em colheita mecanizada. VI Encontro Internacional de Produção Científica Cesumar, EPCC, Maringá.

[2] Santos, N.B. (2011) Identificação dos fatores críticos da colheita mecanizada da cana-de-açúcar. Piracicaba, SP (Dissertação de mestrado).

[3] Conab (2013) Companhia Nacional de Abastecimento. Acompanhamento da Safra Brasileira. Cana-de-açúcar, segundo levantamento, safra 2013/2014. Brasília, 19.

[4] Manhães, C.M.C., Garcia, R.F., Correa Júnior, D., Francelino, F.M.A., Vasconcelos Júnior, J.F.S. and Francelino, H.O. (2013) Perdas quantitativas e danos às soqueiras na colheita de cana-de-açúcar no Norte Fluminense. Vértices, Campos dos Goytacazes, 15, 63-74.

[5] Garcia, R.F. and Silva, L.S. (2010) Avaliação do corte manual e mecanizado de cana-de-açúcar em Campos dos Goytacazes, RJ. Engenharia na agricultura, viçosa-MG, 18, 234-240.

[6] Reis, G.N., Calafange, A., Barreto, A.K.G., Silva, R.P. and Toledo, A. (2010) Onde se perde. Cultivar Máquinas, Pelotas, 10, 34-36.

[7] Mello, R.C. (2005) Influência do formato e velocidade da lâmina nas forças de corte para cana-de-açúcar. Acta Scientiarum Agronomy, Maringá, 27, 661-665.

[8] Benedini, M.S., Brod, F.P.R. and Perticarrari, J.G. (2013) Perdas de cana e impurezas vegetais e minerais na colheita mecanizada. Boletim, 7.

http://xa.Yimg.com/kq/groups/20144470/1118993118/name/Perdas+de+cana+e\%20impurezas+vegetais+e+minerais++CTC.pdf

[9] Ripoli, T.C.C.E. and Ripoli, M.L.C. (2004) Biomassa de cana-de-açúcar: Colheita, energia e ambiente. Barros \& Marques Editoração Eletrônica, Piracicaba, 302.

[10] Empresa Brasileira de Pesquisa Agropecuária_Embrapa (2013) Centro Nacional de Pesquisa de Solos. Sistema brasileiro de classificação de solos. 3rd Edition, Rio de Janeiro, 353.

[11] Reis, G.N. (2009) Perdas na colheita mecanizada da cana-de-açúcar crua em função do desgaste das facas do corte de base. 89 f. (Tese de Doutorado). UNESP—Faculdade de Ciências Agrárias e Veterinárias, Jaboticabal.

[12] Kroes, S. (1997) The Cutting of Sugarcane. 356 f. Tese de Doutorado, University of Southern Queensland, Toowoomba.

[13] Ripoli, T.C.C., Nery, M.S., De León, M.J. and Piedade, S.M.S. (1999) Desempenho operacional de uma colhedora em cana crua em função da velocidade de avanço. Revista Engenharia Agrícola, 19, 199-207.

[14] Ripoli, T.C.C., Nery, M.S., Molina Junior, W.F. and Ripoli, M.L.C. (2001) Operation and Economic Performance of a Green Cane Chopped Harvester in Brazil. ASAE Annual International Meeting, Sacramento, 28 July-1 August 2001.

[15] Carvalho, L.S. (2009) Desempenho operacional de uma colhedora em cana crua na Região da Grande Dourados. MS. Dissertação de Mestrado, Universidade Federal da Grande Dourados, Dourados.

[16] Segato, S.V. and Daher, F. (2011) Perdas visíveis na colheita mecanizada de cana-de-açúcar crua sob velocidades de deslocamento da colhedora. Nucleus, 8, 315-326. http://dx.doi.org/10.3738/1982.2278.471

[17] Silva, R.C., Figueiredo, Z.N. and Caldeira, D.S.A. (2013) Quantificação das perdas visíveis na colheita mecanizada de cana-de-açúcar. In: Congresso de Iniciação Científica, 5ª . (JC), 2013, Cáceres/MT. Anais... Cáceres/MT: Pró-Reitoria de Pesquisa e Pós-Graduação-PRPPG, 2013, Vol. 8.

[18] Neves, J.L.M., Magalhães, P.S.G. and Ota, W.M. (2004) Sistema de monitoramento de perdas visíveis de cana-deaçúcar em colhedora de cana picada. Engenharia Agrícola, 24, 764-770.

[19] Noronha, R.H.F., Silva, R.P., Chioderoli, C.A., Santos, E.P. and Cássia, M.T. (2011) Controle estatístico aplicado ao processo de colheita mecanizada diurna e noturna de cana-de-açúcar. Bragantia, 70, 931-938. http://dx.doi.org/10.1590/S0006-87052011000400028

[20] Silva, R.P., Corrêa, C.F., Cortez, J.W. and Furlani, C.E.A. (2008) Controle estatístico aplicado ao processo de colheita mecanizada de cana-de-açúcar. Engenharia Agrícola, 28, 292-304.

[21] Schogor, A.L.B., Nussio, L.G., Mourão, G.B., Muraro, G.B., Sarturi, J.O. and Matos, B.C. (2009) Perdas das frações de cana-de-açúcar submetida a diversos métodos de colheita. Revista Brasileira de Zootecnia, 38, 1443-1450. http://dx.doi.org/10.1590/S1516-35982009000800007 
Scientific Research Publishing (SCIRP) is one of the largest Open Access journal publishers. It is currently publishing more than 200 open access, online, peer-reviewed journals covering a wide range of academic disciplines. SCIRP serves the worldwide academic communities and contributes to the progress and application of science with its publication.

Other selected journals from SCIRP are listed as below. Submit your manuscript to us via either submit@scirp.org or Online Submission Portal.
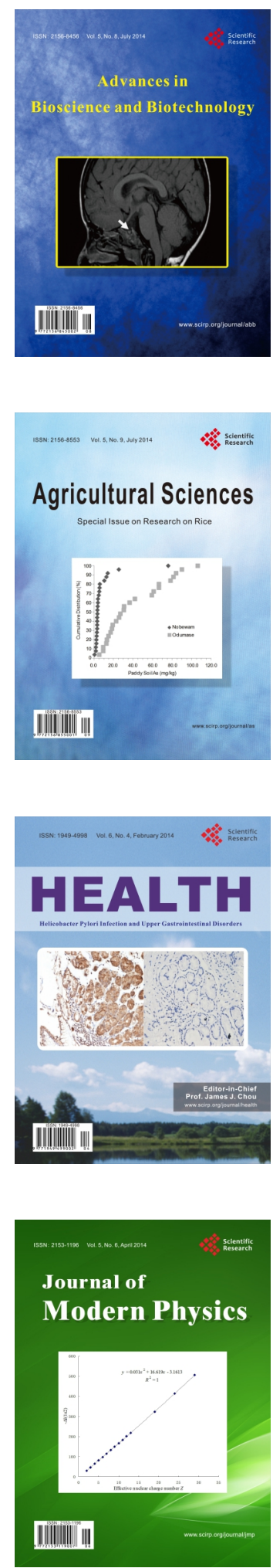
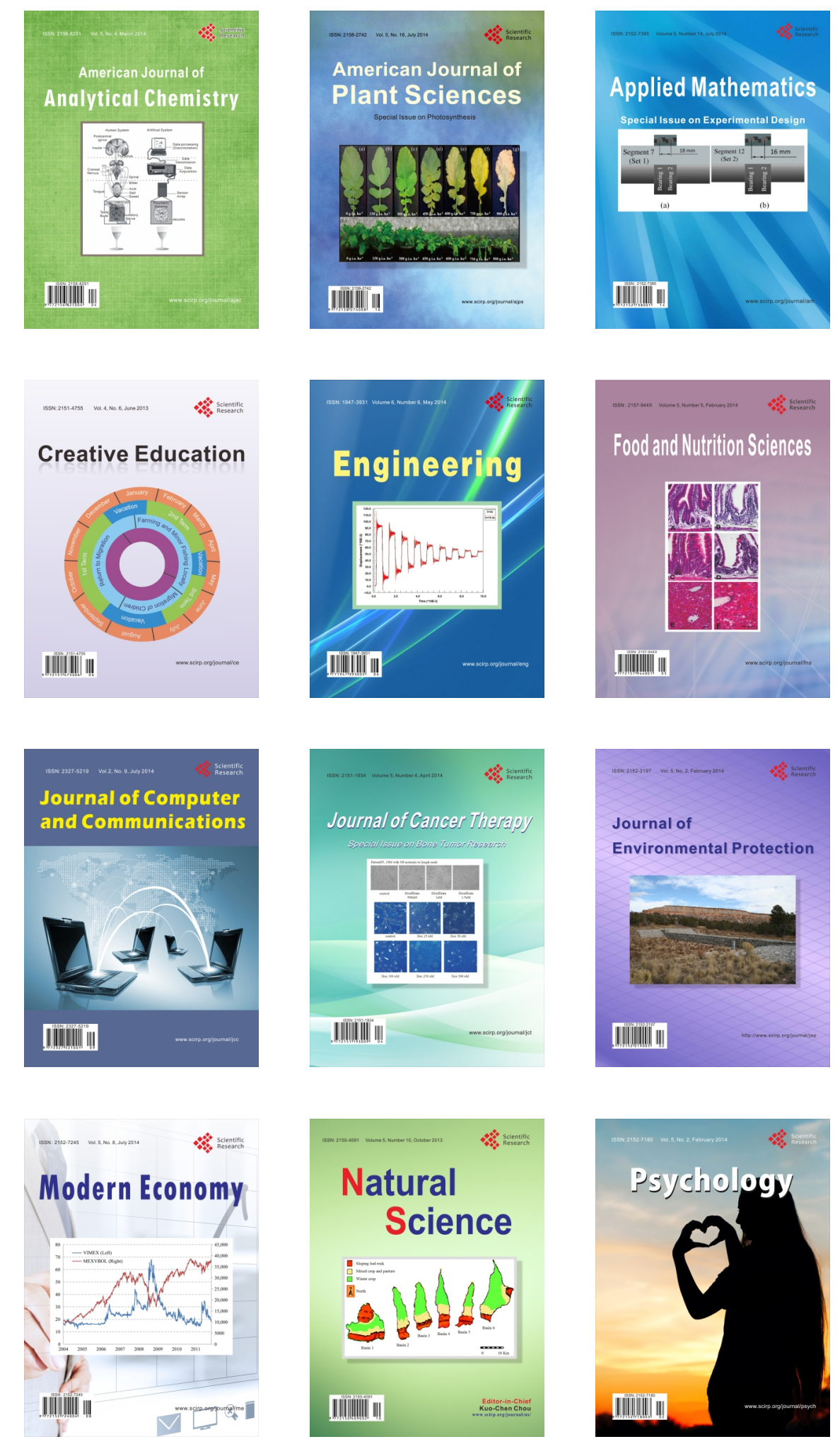